\title{
Testing the Weak-Form Efficiency of the Nairobi Securities Exchange Market
}

\author{
Kamau, Daniel Mburu \\ School of Business, University of Nairobi, Nairobi, Kenya \\ Luther Otieno \\ School of Business, University of Nairobi, Nairobi, Kenya \\ Nixon Omoro \\ School of Business, University of Nairobi, Nairobi, Kenya
}

\begin{abstract}
The study aimed to test whether the Nairobi Securities Exchange Market is efficient in the weak form, specifically if stock prices movements are random or non-random. This study employed explanatory survey design on 20 firms sampled out of 68 listed firms. The parametric auto-correlation test and the non-parametric runs test were employed to test for serial independence in the daily prices. The data didn't follow random walk model which postulates a zero mean. The results, Durbin-Watson Coefficient $=0.169$ indicates non-independent observations. The study rejected the null hypothesis and concluded that NSE firms' daily prices were nonrandom. It is possible that stock market prices are not informative and the market is inefficient in terms of resource allocation. The results is informative to investors and technical analysts to make use of historical data as they predict future prices. The market regulatory body should revise the markets information services and come up with innovative ways to increase free fair and equal dissemination of stock market information. Innovative and superior modeling of past daily prices needed to earn superior profits. Evaluation of factors that make the NSE weak-form inefficient is required implement policies to tackle the causes of inefficiency.
\end{abstract}

Keywords: Weak-Form Efficiency, Stock Prices, Nairobi Securities Exchange Market

DOI: $10.7176 /$ RJFA/10-24-09

Publication date: December $31^{\text {st }} 2019$

\section{Introduction}

The most important theme in finance is that price must reflect the value because investors want value for their money to participate in a capital market. Capital markets channel surplus funds from savers to organizations with projects with a positive net present value but are experiencing a shortage of funds (Ogunrinola and Motilewa, 2015). In capital markets, issues of new stocks are in primary markets while dealing in existing securities or those previously issued in a secondary market, however, the two markets complement each other (Sornette, 2017). An efficient market mirror the organization's earning, growth and financial strength in a security's price, because that is the only way, investors will get value for their money (Cramton \& Ockenfels, 2016).

In 1970, Fama came up with Efficient Market Hypothesis (EMH), a statement that will be tested in this study. Fama's statement was that prices react to new information, but that information is about the future not the past. Therefore, the EMH implies that trading on existing information, apart from not being profitable; tell us about the efficiency in pricing securities in a capital market. The EMH statement is that security's prices respond to new information and because new information arrives randomly it is difficult predicting security's price. No wonder it is Williams (2015) argument that changes in price of stocks must be random movement because there is no motivation to anticipate the new data to be non-arbitrary in appearance. That prices should follow a random walk is also found in Yang, Lee and Lee (2015) who describe the price series as random. Emenike (2017) distinguished three successively weaker versions of the Random Walk based on the distributional characteristics of the price (or return) increments: independently and identically distributed increments, independent increments and uncorrelated increments.

A standout among the most essential standards utilized as a part of estimating the market's efficiency is the capacity of costs to mirror all right now accessible data (Cramton and Ockenfels, 2016). The Efficient Market Hypothesis $(\mathrm{EMH})$ proposes that present stock prices totally reflect every single open information about the firm, new or old. The EMH has gotten a plenitude of consideration since its initiation. Be that as it may, support for or against the EMH is the work in process, and various investigations have archived mixed results. This theory has additionally created extensive discussion (Rossi, 2015). All things considered, the EMH questions the capacity of financial specialists reliably recognizing mispriced securities.

With joined impact of data arriving in a random, autonomous and various contending investors altering stock costs quickly to reflect new data, one would anticipate that value changes will be independent and random. One way of establishing security's market efficiency is by examining the pattern inherent in security's prices, 
specifically whether prices follow a random walk. In Brigham...it pointed out that 'Though the efficient market's hypothesis provides a framework for understanding what information is useful and what is not, we need to validate the hypothesis with real market data. This validation will go on until the results are not mixed. In all test on weak form efficiency seek answer to the question: Does today's stock prices reflect all the data of past prices?

The study tested the following hypotheses;

H01: Traded stock prices movements on the floor of the Nairobi Securities Exchange market are random; $\mathbf{H O}_{2}$ : Traded stock prices movements on the floor of the Nairobi Securities Exchange market are non-random.

\section{Literature Review}

Levy (1967) first advanced the idea of EMH before (Fama, 1970) popularized it. EMH suggests that prices of stocks reflect all information that is available in the market. When prices reflect all information, no investor can benefit because everyone gets the same information. Maverick (2019) statement is that 'the market cannot be beaten because it incorporates all important determinative information into current share prices.

Levy (1967) proposed two forms of EMH - weak and strong forms, Professor Roberts (1959) suggested the three levels of market efficiency by adding strong form, but did not think it worth researching on. I $t$ appears Eugene Fama furthered on Professor Roberts work. The three forms reflect a different set of information and level of efficiency. That is, market efficiency is about the degrees to which security's price reacts to information.

The weak form mirrors a random walk model of short-term price movements and upholds that there should be no patterns in the security's prices because the stock value captures all historical data about securities, such as daily prices and trading volume. (Nwachukwu \& Shitta, 2015). Therefore, no investor can gain excessive profits by predicting the stock prices based on such past information, because that information is already incorporated into share prices (Fama, 1970). A market that fails to discount existing information in the share price is by all definitions inefficient in pricing securities in that market. Relevant information for purpose of security valuation is about the future. Semi-strong form assumes that stock prices adjust rapidly to reflect all public information received (Nwachukwu \& Shitta, semi-strong predict that the stock prices completely reflect all data from open and private sources (Nwachukwu \& Shitta, 2015). The strong form also assumes that markets are efficient to an extent that the information impacts on price occur before the information is published.

The simple random walk theory suggests that because information arrives randomly, the share price changes are unpredictable. Samuelson (1965) formalized the belief among that security market prices are unbiased and are a reflection of supply and demand, and is random. The Random Walk model accept that progressive value changes (or daily prices) are independently and identically distributed random variables, ruling out predictability of future price changes from previous price changes (Fama, 1965). In a weak form efficient market, i.e. where stock market prices fully reflect all past market historical market data to predict share prices. It is not possible relying on historical data to select stocks and earn excess profits from those stocks (Cleary, et al., 2011). Thus, researchers use the random walk hypothesis (RWH) to study EMH. The assumption is that stocks that follow a random walk are efficient in the weak form. Indeed, studies that test EMH assumes the RWH, and then proceed to prove otherwise. This study adopted RWH as a basis for testing EMH for stocks listed on the Nairobi Securities Exchange.

Al-Loughani \& Chappell (1997) studied the validity of weak form EMH for London's stocks and found no evidence that the series followed RWH hence no weak-form efficiency of the market. Narayan et al., (2015) tested whether EMH is day-of-the-week-dependent using stocks from banks listed in NYSE. The study found no evidence of EMH for individual bank stocks. Al-Khazali \& Mirzaei (2017) using Dow Jones Islamic Market Index (DJIMI) used both AMH and EMH frameworks and found that AMH better explained calendar anomalies affecting market efficiency of Islamic stocks than the EMH.

Omran \& Farrar (2006) investigated the RWH in Middle Eastern countries and rejected the RWH for all the markets examined. Jarrett (2010) studied the Asian market in a bid to test EMH and revealed that the weak form EMH did not hold for the four markets (Singapore, Malaysia, Korea and Indonesia) examined. Mishra et al. (2015) showed that Indian stocks were means reverting thus no evidence of weak form efficiency. Malafeyev et al. (2017) studying China and India to test the effect of global financial crisis on the efficiency of stock markets revealed that both markets did not exhibit weak form efficiency and that the crisis did not affect the market efficiency. A study in Bangladesh by Feige (2016) investigated the independent movements in the prices and volumes of stocks and concluded that cost and volume responses are autonomous and firmly related.

OpokuOpoku (2016) studied the weak form efficiency of African stock markets by selecting 24 stocks indexes and eight individual national stocks and found that the stocks were weak form efficient; and that the continent-wide indexes were more weak-form efficient than the national stocks. Using 30 stocks from Kenya, Kelikume (2016) found that the stocks were efficient in the weak form. In Ethiopia, the Independent movement in the prices of stocks traded is influenced by malpractices where an investment bank oversees an issue while a business department of the same bank trades in those shares prior to an issue of the company. There are circumstances where analyst compensations for research work and investment banking businesses are connected. 
Murithi (2013) studied the weak-form efficiency of NSE and found that the stocks did not follow a random walk. Kamau (2013) also found that NSE stocks were not weak form efficient. Chesire (2014) also found no evidence for weak form EMH when she examined weak form EMH for KenGen and KPLC shares prices.

\section{Research Methodology}

The target population for this study will be all 68 listed firms in the NSE for the period 2002-2017 (NSE handbook, 2017). The study selected 20 firms that constitute the NSE twenty share index and represent over 60 percent of market capitalization in that market. The test is to establish whether the daily price dynamic at the NSE follows a random walk process. The researcher used inferential statistics to try to infer from the daily price data how the population of stocks in the NSE behaves. Kolmogorov-Smirnov goodness of fit test was used together with the descriptive statistics obtained to test the distribution of the return series. In addition, parametric auto-correlation test and the non-parametric run's test were employed to test for serial independence in the daily prices.

\section{Findings and Discussions}

Findings on descriptive analysis were as presented in table 1 below. The (missing observations in table 1 for some firms was because the observed data started from 2002 when some firms had not been started).

Table 1: Descriptive Statistics of the NSE Firms

\begin{tabular}{|c|c|c|c|c|c|c|c|c|c|c|c|}
\hline & ARM & BAMBURI & BBK & BAT & ICDCI & CFC & EABL & KCB & KENOL & KQ & KPLC \\
\hline Observation & 3811 & 3321 & 3818 & 3311 & 3818 & 3825 & 3815 & 3818 & 3818 & 3818 & 3818 \\
\hline Mean & 75.1 & 147.2 & 85.3 & 284.6 & 43.5 & 68.7 & 219.0 & 47.3 & 67.5 & 29.8 & 79.37 \\
\hline Median & 72.5 & 158 & 57.25 & 205 & 32 & 65.5 & 194 & 32.5 & 49 & 14 & 25 \\
\hline Mode & 91 & 200 & 17 & 200 & 60 & 9 & 145 & 23 & 100 & 6 & 9 \\
\hline Std. Dev & 56.24 & 54.64 & 93.37 & 207.4 & 49.64 & 36.84 & 98.07 & 43.14 & 80.47 & 30.87 & 80.43 \\
\hline Min & 0 & 0 & 7 & 0 & 9 & 0 & 74 & 8 & 0 & 3 & 6 \\
\hline Max & 235 & 240 & 602 & 999 & 553 & 368 & 552 & 271 & 423 & 146 & 335 \\
\hline & NMG & SASINI & SCBK & BRITAM & \multicolumn{2}{|c|}{ COOP } & EQTY & KENGEN & \multirow{2}{*}{\multicolumn{2}{|c|}{ SAFCOM }} & SCAN \\
\hline Observation & 3813 & 3803 & 3815 & 1363 & \multirow{2}{*}{\multicolumn{2}{|c|}{$\begin{array}{l}2144 \\
3628\end{array}$}} & 2711 & 2766 & \multirow{2}{*}{\multicolumn{2}{|c|}{$\begin{array}{l}2279 \\
3628\end{array}$}} & 2685 \\
\hline Missing & 0 & 0 & 0 & 97 & & & 3628 & 3628 & & & 3640 \\
\hline Mean & 187.5 & 19.02 & 192.7 & 12.93 & \multicolumn{2}{|c|}{15.18} & 62.22 & 14.68 & \multicolumn{2}{|c|}{$\begin{array}{l}3028 \\
9.16\end{array}$} & 38.09 \\
\hline Median & 178 & 15.55 & 189 & 10.40 & & & 33.75 & 12.30 & \multicolumn{2}{|c|}{5.85} & 32.75 \\
\hline Mode & 180 & 20 & 140 & 10 & \multicolumn{2}{|c|}{20} & 24 & 7 & \multicolumn{2}{|c|}{4} & 26 \\
\hline Std. Dev & 78.3 & 17.169 & 72.75 & 7.461 & \multirow{2}{*}{\multicolumn{2}{|c|}{$\begin{array}{l}4.058 \\
6\end{array}$}} & 65.83 & 7.651 & \multicolumn{2}{|c|}{6.008} & 15.63 \\
\hline Min & 0 & 3 & 46 & 4 & & & 12 & 5 & \multicolumn{2}{|c|}{3} & 10 \\
\hline Max & 398 & 177 & 355 & 37 & \multicolumn{2}{|c|}{24} & 324 & 40 & \multicolumn{2}{|c|}{25} & 76 \\
\hline
\end{tabular}

The values of Skewness and kurtosis coefficients (see table 2) were all above 5\% level of significance suggesting the absence of normally distributed.

Table 2 Skewness and Kurtosis

\begin{tabular}{|c|c|c|c|c|c|c|c|c|c|c|c|}
\hline Category & ARM & \multicolumn{2}{|c|}{ BAMBURI } & BBK & BAT & ICDCI & CFC & EABL & KCB & KENOL & KQ \\
\hline Skewness & 0.574 & -0.901 & & 1.445 & 1.47 & 4.91 & 1.15 & 1.169 & 2.534 & 2.057 & 1.36 \\
\hline Kurtosis & -0.383 & 0.019 & & 2.127 & 1.49 & 28.711 & 5.79 & 0.778 & 6.732 & 4.611 & 0.98 \\
\hline Category & KPLC & NMG & $\begin{array}{l}\text { SASIN } \\
\text { I }\end{array}$ & SCBK & BR & $\mathrm{M}$ & COOP & EQTY & KENGEN & SAFCOM & SCAN \\
\hline Skewness & 0.672 & 0.116 & 5.202 & 0.211 & & & -0.245 & 1.976 & 1.152 & 0.637 & 0.49 \\
\hline Kurtosis & -0.819 & -0.721 & 30.403 & -0.629 & & & -0.817 & 3.305 & 0.603 & -1.041 & -0.95 \\
\hline
\end{tabular}

The study finding also indicated that majority of data were positively skewed. These study findings of positive skewness for the daily data in NSE concur with study findings of Vitali and Mollah (2010), in Tunisia, Kenya and Mauritius. However, Borges (2007), noted negative values for all the daily samples in the Pakistan market. As per Elbarghouthi, et al. (2012), skewness is a measure of asymmetry of the distribution of the series around its mean. The significant positive skewness in NSE firm daily prices give an implication that large positive daily prices tend to be larger than the higher negative daily prices hence data are not symmetrical distribution.

The study results for Kolmogorov-Smirnov Goodness of Fit Tests were presented in table 3. 
Table 3 Kolmogorov-Smirnov Goodness of Fit Tests

\begin{tabular}{|c|c|c|c|c|c|c|}
\hline & \multicolumn{3}{|c|}{ Kolmogorov-Smirnov ${ }^{\mathrm{a}}$} & \multicolumn{3}{|c|}{ Shapiro-Wilk } \\
\hline & Statistic & Df & Sig. & Statistic & Df & Sig. \\
\hline ARM & 0.124 & 3311 & 0.000 & 0.929 & 3311 & 0.000 \\
\hline BAMBURI & 0.111 & 3311 & 0.000 & 0.912 & 3311 & 0.000 \\
\hline BBK & 0.239 & 3311 & 0.000 & 0.801 & 3311 & 0.000 \\
\hline BAT & 0.235 & 3311 & 0.000 & 0.816 & 3311 & 0.000 \\
\hline ICDCI & 0.256 & 3311 & 0.000 & 0.494 & 3311 & 0.000 \\
\hline CFC & 0.079 & 3311 & 0.000 & 0.917 & 3311 & 0.000 \\
\hline EABL & 0.16 & 3311 & 0.000 & 0.882 & 3311 & 0.000 \\
\hline KCB & 0.198 & 3311 & 0.000 & 0.684 & 3311 & 0.000 \\
\hline KENOL & 0.206 & 3311 & 0.000 & 0.746 & 3311 & 0.000 \\
\hline KQ & 0.188 & 3311 & 0.000 & 0.807 & 3311 & 0.000 \\
\hline KPLC & 0.22 & 3311 & 0.000 & 0.852 & 3311 & 0.000 \\
\hline NMG & 0.098 & 3311 & 0.000 & 0.966 & 3311 & 0.000 \\
\hline SASINI & 0.279 & 3311 & 0.000 & 0.454 & 3311 & 0.000 \\
\hline SCBK & 0.067 & 3311 & 0.000 & 0.966 & 3311 & 0.000 \\
\hline BRITAM & 0.147 & 1363 & 0.000 & 0.894 & 1363 & 0.000 \\
\hline COOP & 0.073 & 2144 & 0.000 & 0.975 & 2144 & 0.000 \\
\hline EQTY & 0.315 & 2711 & 0.000 & 0.689 & 2711 & 0.000 \\
\hline KENGEN & 0.131 & 2766 & 0.000 & 0.879 & 2766 & 0.000 \\
\hline SAFCOM & 0.214 & 2279 & 0.000 & 0.858 & 2279 & 0.000 \\
\hline SCAN & 0.151 & 2685 & 0.000 & 0.929 & 2685 & 0.000 \\
\hline
\end{tabular}

The Kolmogorov-Smirnov value less than 0.05 is considered not normal at sig. $<0.05$. The value for Shapiro-Wilk less than 0.05 indicate non-normality (Sig. <0.05). This implies that data was considered not to come from a normal distribution. Therefore, distribution of the NSE firms daily prices are not coming from normally distributed population. The study findings concur with study finding of Elbarghouthi, et al., (2012); Mlambo and Biekpe (2003); Mollah (2007); Simons and Laryea (2005); Vitali and Mollah (2010) who found out that return from emerging markets are not normally distributed. Auto-Correlation Tests gave the results presented in table 4.

Table 4: Auto-Correlation Coefficients

\begin{tabular}{llllll}
\hline Model & R & R Square & $\begin{array}{l}\text { Adjusted R } \\
\text { Square }\end{array}$ & $\begin{array}{l}\text { Std. Error of the } \\
\text { Estimate }\end{array}$ & $\begin{array}{l}\text { Durbin- } \\
\text { Watson }\end{array}$ \\
\hline $\mathbf{1}$ & $.978 \mathrm{a}$ & .956 & .955 & .589 & .169 \\
\hline
\end{tabular}

Autocorrelation also known as lagged correlation or serial correlation, measures the relationship between a variable's current value and its past values. Autocorrelation occurs when residuals are not independent of each other. The assumption of independence of residuals implies that successive observations of the dependent variable are not correlated. This means that successive residuals have no pattern and there are no long runs of positive or negative residuals. Durbin-Watson statistic was used to test for autocorrelation. The value of the Durbin-Watson statistic can range from 0 to 4 . The value of Durbin-Watson statistic is 2.0 when there is no autocorrelation among the residuals. It gets close to 0 when there is positive autocorrelation and is beyond 2 when there is negative autocorrelation (Lind, Marchal \& Wathen, 2012). The value of Durbin-Watson coefficient in this study was found to be 0.169 indicating non independent observations and absence of random walk in share prices.

Run test was done in order to test independence of data. Findings were as presented in table 5. 
Table 5 Runs Test Results

\begin{tabular}{llllll}
\hline & Test Value & Total Cases & Number of Runs & Z & Sig. (2-tailed) \\
\hline ARM & 75.1 & 3811 & 45 & -60.314 & 0.000 \\
BAMBURI & 147 & 3321 & 54 & -55.715 & 0.000 \\
BBK & 85.37 & 3818 & 19 & -61.066 & 0.000 \\
BAT & 284.66 & 3311 & 10 & -57.159 & 0.000 \\
ICDCI & 43.58 & 3818 & 33 & -60.66 & 0.000 \\
CFC & 69.35 & 3794 & 50 & -60.007 & 0.000 \\
EABL & 219.09 & 3815 & 26 & -60.947 & 0.000 \\
KCB & 47.3 & 3818 & 35 & -60.548 & 0.000 \\
KENOL & 67.52 & 3818 & 14 & -61.36 & 0.000 \\
KQ & 29.81 & 3818 & 11 & -61.435 & 0.000 \\
KPLC & 79.37 & 3818 & 5 & -61.667 & 0.000 \\
NMG & 187.56 & 3813 & 49 & -60.168 & 0.000 \\
SASINI & 19.02 & 3803 & 80 & -58.466 & 0.000 \\
SCBK & 192.17 & 3815 & 64 & -59.727 & 0.000 \\
SCAN & 38.09 & 2685 & 25 & -50.895 & 0.000 \\
SAFCOM & 9.16 & 2279 & 4 & -47.62 & 0.000 \\
KENGEN & 14.68 & 2766 & 30 & -51.46 & 0.000 \\
EQTY & 62.22 & 2711 & 2 & -52.031 & 0.000 \\
COOP & 15.18 & 2144 & 22 & -45.406 & 0.000 \\
BRITAM & 12.93 & 1363 & 18 & -35.957 & 0.000 \\
\hline
\end{tabular}

The finding is $\mathrm{Z}$ statistics value for all firms have negative signs, giving an indication that the run numbers observed were less than the expected numbers of runs for daily price data for NSE selected firms, except for Sasini, Kengen, Co-operative and Britam, which had observed number of runs more than expected numbers of runs. Negative $Z$ values indicate positive serial correlation in the return series (Elbarghouthi,et al., 2012).

The observed differences between the actual and the expected number of runs, expressed as a two-tailed is significant. Therefore, the study data rejected the null hypothesis that the traded stock prices movements in NSE firms are completely random. The data reject the null hypothesis that the successive return changes are not independent, hence traded prices movements in NSE firms market exhibit a pattern for some firms, weak form efficient. However, the daily prices Sasini, Kengen, Co-operative and Britam which had observed number of runs more than expected numbers of runs follow a random walk.

The study findings agreed with the study results of Waweru, Munyoki and Uliana (2008) on the NSE, Emenike (2008) on the Nigeria Stock Exchange and Elbarghouthi, et al. (2012), on the Amman Stock Exchange, when the expected number of runs were significantly higher than the observed number of runs in the respective markets. The study findings also agreed with study findings of Vitali and Mollah (2010) who rejected the null hypothesis of the return series being a random. However, the study findings fail to agree with study findings of Dickinson and Muragu (1994) who failed to reject the null hypothesis of independence at the $5 \%$ level for the NSE daily prices.

\section{Conclusions and Recommendations}

The study concluded that in 16 out of the 20 firms sampled, the run numbers observed in the majority of the firms were less than the expected numbers of runs for daily price data for NSE firm. Therefore, the study rejected the null hypothesis and concluded that NSE firm's daily price data were non-random. The successive return changes are not independent, hence traded stock price's movement in NSE is not a weak form efficient. This implies that investors and technical analysts are in a position to make use of historical data as they will be able to predict future prices. In all, NSE is not informatio efficient. The market regulatory body should revise the markets information services and come up with innovative ways to increase free fair and equal dissemination of stock market information to all participants.

\section{References}

1) Aitken, M. J., Aspris, A., Foley, S., \& Harris, F. H. D. B. (2018). Market fairness: The poor country cousin of market efficiency. Journal of Business Ethics, 147(1), 5-23.

2) Al-Khazali, O., \& Mirzaei, A. (2017). Stock Market Anomalies, Market Efficiency and the Adaptive Market Hypothesis: Evidence from Islamic Stock Indices. Journal of International Financial Markets, Institutions \& Money, 1-48.

3) Al-Loughani, N., \& Chappell, D. (1997). On the Validity of the Weak-Form Efficient Market Hypothesis Applied to the London Stock Exchange. Applied Financial Economics, 7, 173-176. 
4) Alsahlawi, A. M., \&Ammer, M. A. (2017). Corporate Governance, Ownership Structure and Stock Market Liquidity in Saudi Arabia: A Conceptual Research Framework. Accounting and Finance Research, 6(4), 17.

5) Bamiatzi, V., Bozos, K., Cavusgil, S. T., \&Hult, G. T. M. (2016). Revisiting the firm, industry, and country effects on profitability under recessionary and expansion periods: A multilevel analysis. Strategic management journal, 37(7), 1448-1471.

6) Baporikar, N., Nambira, G., \&Gomxos, G. (2016).Exploring factors hindering SMEs' growth: evidence from Nambia. Journal of Science and Technology Policy Management, 7(2), 190-211.

7) Charfeddine, L., \& Khediri, K. B. (2016). Time Varying Market Efficiency of the GCC Stock Markets. Physica A: Statistical Mechanics and its Applications, 444, 487-504.

8) Chesire, E. J. (2014). Testing the weak form of efficient market hypothesis at Nairobi Stock Exchange. Nairobi: University of Nairobi.

9) Cramton, P., \&Ockenfels, A. (2016).Economics and design of capacity markets for the power sector. In InterdisziplinäreAspekte der Energiewirtschaft (pp. 191-212). Springer Vieweg, Wiesbaden.

10) Elbarghouthi, S., Qasim, A., \& Yassin, M. (2012). The use of runs test in Amman Stock Exchange. International Business Research, 5(2), 159.

11) Emenike, K. O. (2008). Efficiency across time: Evidence from the Nigerian Stock exchange.

12) Engdawork, P., \& Ababa, A. (2015).Assessment of Corporate Governance Practice in Private Banks of Ethiopia.

13) Fama, E. F. (1965). The Behaviour of Stock Market Prices. Journal of Business, 39, 242-255.

14) Feige, E. L. (2016). Defining and estimating underground and informal economies: the new institional economics approach.

15) Gilson, R. J., \&Kraakman, R. (2014). Market efficiency after the financial crisis: It's still a matter of information costs. Virginia Law Review, 313-375.

16) Gresse, C. (2017). Effects of lit and dark market fragmentation on liquidity. Journal of Financial Markets, $35,1-20$

17) Issahaku, H., Abor, J. Y., \& Harvey, S. K. (2017). Remittances, banks and stock markets: Panel evidence from developing countries. Research in International Business and Finance, 42, 1413-1427.

18) Kamau, A. M. (2013). An Empirical Analysis of the Weak Form Efficient Market Hypothesis of the Nairobi Securities Exchange. Nairobi: KCA University.

19) Kelikume, I. (2016). New evidence from the efficient market hypothesis for the Nigerian stock index using the wavelet unit root test approach. The Journal of Developing Areas, 50(5), 185-197.

20) Khan, W., \& Vieito, J. P. (2012). Stock Exchange Mergers and Weak Form of Market Efficiency: The case of Euronext Lisbon. International Review of Economics and Finance, 22, 173-189.

21) Lean, H. H., \& Smyth, R. (2015). Testing for Weak-Form Efficiency of Crude Palm Oil Spot and Future Markets: New Evidence from a GARCH Unit Root Test with Multiple Structural Breaks. Applied Economics, 47(16), 1710-1721.

22) Levy, R. (1967). The Theory of Random Walks: A Survey of Findings. The American Economist, 11, 34-48.

23) Malafeyev, O., Awasthi, A., \& Kambekar, K. S. (2017). Random Walks and the Market Efficiency in Chinese and Indian Equity Markets. 1-48.

24) Mayowa, G. A., \& Osayuwu, R. (2012). Testing the Weak Form of Efficient Market Hypothesis in Nigerian Capital Market. Accounting and Finance Research, 1(1), 169-179.

25) Mishra, A., Mishra, V., \& Smyth, R. (2015). The Random-Walk Hypothesis on the Indian Stock Market. Emerging Markets Finance \& Trade, 51(5), 879-892.

26) Mlambo, C., \& Biekpe, N. (2007). The Efficient Market Hypothesis: Evidence from Ten African Stock Markets. Investment Analysts Journal, 36(66), 5-17.

27) Narayan, P. K., Narayan, S., Popp, S., \& Ahmed, H. A. (2015). Is the Efficient Market Hypothesis Day-ofthe-Week Dependent? Evidence from the Banking Sector. Applied Economics, 47(23), 2359-2378.

28) Ndungu, G. R. (2014). An investigation on the month of the year anomaly in the Nairobi securities exchange in, Kenya. Unpublished MBA project.

29) Njuguna, J. M. (2015). An investigation of the market efficiency of the Nairobi Securities Exchange. Johannesberg: University of South Africa.

30) Nwachukwu, J. C., \& Shitta, O. (2015). Testing the weak-form efficiency of stock markets: a comparative study of emerging and industrialised economies. International Journal of Emerging Markets, 10(3), 409-426.

31) Omran, M., \& Farrar, S. V. (2006). Tests of Weak Form Efficiency in the Middle East Emerging Markets. Studies in Economics and Finance, 23(1), 13-26.

32) Opoku, L. O. (2016). Investor reactions to news about firms listed on the Ghana Stock Exchange (Doctoral dissertation).

33) Phan, K. C., \& Zhou, J. (2014). Market efficiency in emerging stock markets: A case study of the Vietnamese stock market. IOSR Journal of Business and Management, 16(4), 61-73. 
34) Righi, M. B., \& Ceretta, P. S. (2013). Risk Prediction Management and Weak Form Market Efficiency in Eurozone Financial Crisis. International Review of Financial Analysis, 30, 384-393.

35) Rossi, M. (2015). The efficient market hypothesis and calendar anomalies: a literature review. International Journal of Managerial and Financial Accounting, 7(3-4), 285-296. 